\title{
Design of Worksheets for RME Model to Improve Mathematical Communication
}

\author{
Joko Supriyanto ${ }^{1}$, Suparman ${ }^{1, *}$, Yahya Hairun ${ }^{2}$ \\ ${ }^{1}$ Department of Mathematics Education, Faculty of Teacher Training and Education, Ahmad Dahlan University, Indonesia \\ ${ }^{2}$ Department of Mathematics Education, Faculty of Teacher Training and Education, Khairun University, Indonesia
}

Received December 12, 2019; Revised January 7, 2020; Accepted February 3, 2020

Copyright $(2020$ by authors, all rights reserved. Authors agree that this article remains permanently open access under the terms of the Creative Commons Attribution License 4.0 International License

\begin{abstract}
Students in mathematics learning activities must have mathematical communication skills. They are using mathematical concepts to contextual problems so that understanding is more meaningful and links mathematics learning with other learning topics. Student worksheets are one of the teaching materials that summarize the material and study guides that are in accordance with the competencies. The purpose of this article is to develop the design of student worksheets to improve students' mathematical communication in learning activities with an RME approach. In its development, the ADDIE model was applied in this study, which consisted of four steps: first analysis, second design, third development, fourth implementation, and the fifth evaluation. The subjects of this study were students of Muhammadiyah 1 Yogyakarta Yogyakarta Vocational School. The instruments of data collection consist of interview guideline sheets, document sheets, and description sheets. Interview guideline sheets are used to obtain data in the curriculum and character of students, and document sheets are used to evaluate teaching materials, and description sheets are used to determine the improvement of students' mathematical communication. This data was analyzed using qualitative data analysis. This study resulted in the design of worksheets of students with RME approach to improve students' mathematical communication skills.
\end{abstract}

Keywords ADDIE, Mathematical Communication, RME, Worksheet

\section{Introduction}

[1] Mathematics is one of the most important subjects and is a compulsory subject in schools from elementary school to college. Mathematics can be used as essential capital in life, mainly used to solve everyday problems. Mathematics also has a flow of systematic thinking, following rules that have become guidelines, and special agreements. The brain that is used to learning mathematics will get used to thinking systematically. The reality can be produced and every problem that exists in this world can be easily found a solution. In addition, other sciences such as physics, biology, chemistry, language, and others can be easily understood through mathe matics. Therefore students will have obstacles to understand the lessons of other learning if students experience difficulties in learning mathematics. For that learning, mathematics is very important because the higher level of thinking of students can be developed. but, in contrast to reality, students are mostly afraid and avoid learning mathematics. With this, it can be seen that the teacher needs to make the learning system more interesting and fun for students so that the learning objectives are achieved.

Mathematical communication skills are used to produce mathematical creations (including mathematical representations, solutions, and solutions to the explanation of word problems) [2]. Mathe matical commun ication skills are used to foster high-level thinking skills of students and mathe matical understanding [3]. The approach so far in the classroom by the mathematics teacher has not been able to actualize the students' creative thinking skills [4]. Communication opportunities between other students to interact in class have not been provided by many teachers. Learning in the classroom is still largely teacher-centered [5].

The use of problem-based learning models and discoveries towards students provides a better mathematical communication effect than conventional learning designs. In elementary school, the discovery learning model is more effectively used to improve students' mathematical communication skills. At the high school level and above, problem-based learning design and effective discovery models are used for mathe matical commun ication skills [6]. Self-confidence or self-confidence influences mathematical 
communication skills [7]. What teachers need to do is to help students build social and emotional abilities through conditioning and create conducive classes that will later achieve increased learning for students [8]. Students in the class are expected to not only communicate using algebra and geometry but also use other language models to be able to share mathematical knowledge and exchange ideas with others [9]. In other cases, with the use of problem-based learning models, students' mathematical communication skills can be improved [10].

Learning mathematics in class must be done well, one of which is to prepare preparations. A mong the preparation is preparing teaching materials. Among the teaching materials that can be prepared are student worksheets which is usually known as the LKPD. The teacher must be able to make or prepare the teaching materials properly so that the learning process that takes place can improve students' creative abilities [11]. Student worksheets are sheets that contain tasks that must be done by students. Teachers must be careful and have skills in preparing student worksheets so that the activities of students fulfill the competency criteria to be achieved [12]. Learning obtained by students in schools can be related to their real life.

Meaningful lessons obtained in schools are arranged in a planned manner [13]. Based on the results of research [14] worksheets of students with RME approach have characteristics using real-world context, construction, mathematical processes, interactivity, and integrated learning. The development of teaching materials for student worksheets is now widely carried out by many researchers, including [11][15-20].

According to the ability of students to understand, the teacher needs teaching materials that cover everyday life problems (contextual) [21]. Based on these problems, good learning planning is needed so that learning in the classroom can be effective so that ultimately the learning objectives can be achieved properly. One plan that must be prepared is a student worksheet that is in accordance with the abilities to be achieved, of course, by choosing the appropriate learning model. This article has the goal of developing student worksheets based on the learning model of the Realistic Mathematics Education Class X of Muhammadiyah 1 Vocational School Yogyakarta in Indonesia.

\section{Research and Methods}

This type of research is development. In this study, Student Worksheets were developed based on the Realistic Mathematics Education learning model to improve students' mathematical communication skills. Development of Student Worksheets is carried out using the ADDIE model, which consists of Analysis, design, development, implementation, and evaluation. The ADDIE model flow can be seen in figure 1 below:

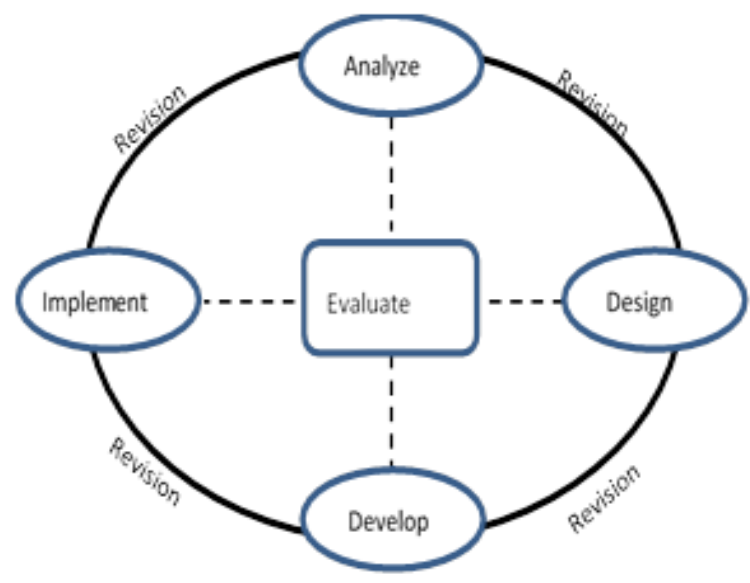

Figure 1. ADDIE [22]

Analysis, design, development, implementation, and evaluation are the stages that will be passed on the ADDIE model [23]. First, the analysis includes the educational objectives to be achieved and to achieve the educational objectives, it is planned what needs to be taught. In the second stage of design, educators create various explanations that explain the ways in conveying work steps to fulfill the objectives carried out from the previous process, namely analysis. The third stage is development, and the parts of the work step are shown in a clear and practical form. In the fourth stage, namely implementation. The steps that have been made are applied in activities in the classroom together with students to find out the results. And finally, the fifth phase is evaluation. Input, or feedback obtained is used to improve the design of the activity and make adjustments to the subsequent teaching activities [16]. This research was conducted at Muhammadiyah 1 Yogyakarta Vocational School in the odd semester of the 2018/2019 academic year. The research subjects were X class students consisting of 70 students. The method of data collection is done by using the interview and test guideline sheets.

In this study, the average research results from the product design expert validator were obtained using the following formula:

$$
\overline{\mathrm{X}}=\sum_{i=1}^{n} X_{i} / \mathrm{n}
$$

Information:

$\overline{\mathrm{X}}$ : average score Worksheet design score

$X_{i}$ : score determines the indicator to $i$, if $i=1,2,3, \ldots, n$ $n:$ number of studies

The data obtained is then classified as in table 1 below:

Table 1. Score classification table

\begin{tabular}{|c|c|}
\hline Score Range & Criteria \\
\hline $\mathrm{X}>4.2$ & Very good \\
\hline $3,4<\mathrm{X}<4,2$ & Good \\
\hline $2,6<\mathrm{X}<3,4$ & Enough \\
\hline $1,8<\mathrm{X}<2,6$ & Less \\
\hline $\mathrm{X}<1,6$ & Very less \\
\hline
\end{tabular}


Determination of product design validity was obtained in accordance with the classification obtained on average from a good minimum validator.

\subsection{Analysis}

The first stage of developing student worksheets based on the ADDIE model is Analysis. The analysis consists of analysis of needs in the classroom and analys is of student characters. Conclusions can be obtained from the analysis of needs: 1) learning activities that should be centered on students are still centered on the teacher so that students' understanding is not maximal; 2) the worksheets of students used have not accommodated the ability of students to build their knowledge, but the worksheets contained more material, formulas, examples and short exercises that students may not necessarily understand. While based on the results of character analysis students obtained information: 1) students solve problems only by memorizing existing formulas; 2) when students conduct group discussions, they are still passive and lack confidence in conveying their ideas; 3) when in the session of communication, students tend to be quiet and not give a response. In the next step, which is the second step, a worksheet will be made in accordance with the design that has been made. That is making design covers, basic competency sheets, introductory sheet designs, table of contents designs, contextual problem design, sheet design, sample questions to the design of practice questions. In the next step, after making the initial design of the student worksheet, then the study is proceeded with a validation test by media experts. Suggestions and input from the validator are obtained and used to improve the worksheet of students [14].

\subsection{Design}

Based on the analysis, the things done at this design stage are planning the contents on the student worksheet. The contents of each sheet cons ist of the first sheet of cover. The parts on the cover sheet consist of titles, subject matter, class, author's name, and images that have a dark background with additional images related to rows and rows.

This cover is made interesting so that students as users who see it later will be interested so they want to hold and will open sheet after sheet of this worksheet. The quality of the paper which will later be used is thicker so that it is more resistant to damage. A plan for the cover of the student worksheet can be seen in the following figure 2 :

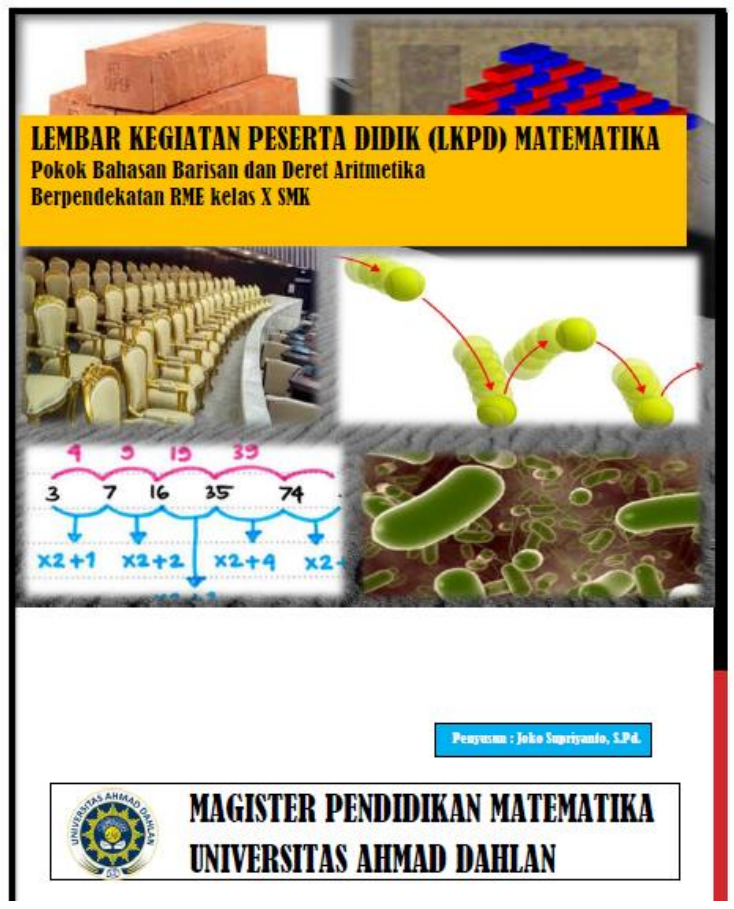

Figure 2. Cover of Student Worksheets

The second sheet is the introduction such an introductory word of thanks, brief content from the media and an open suggestion for the results that have been made. Preface design can be seen in figure 3 below: 


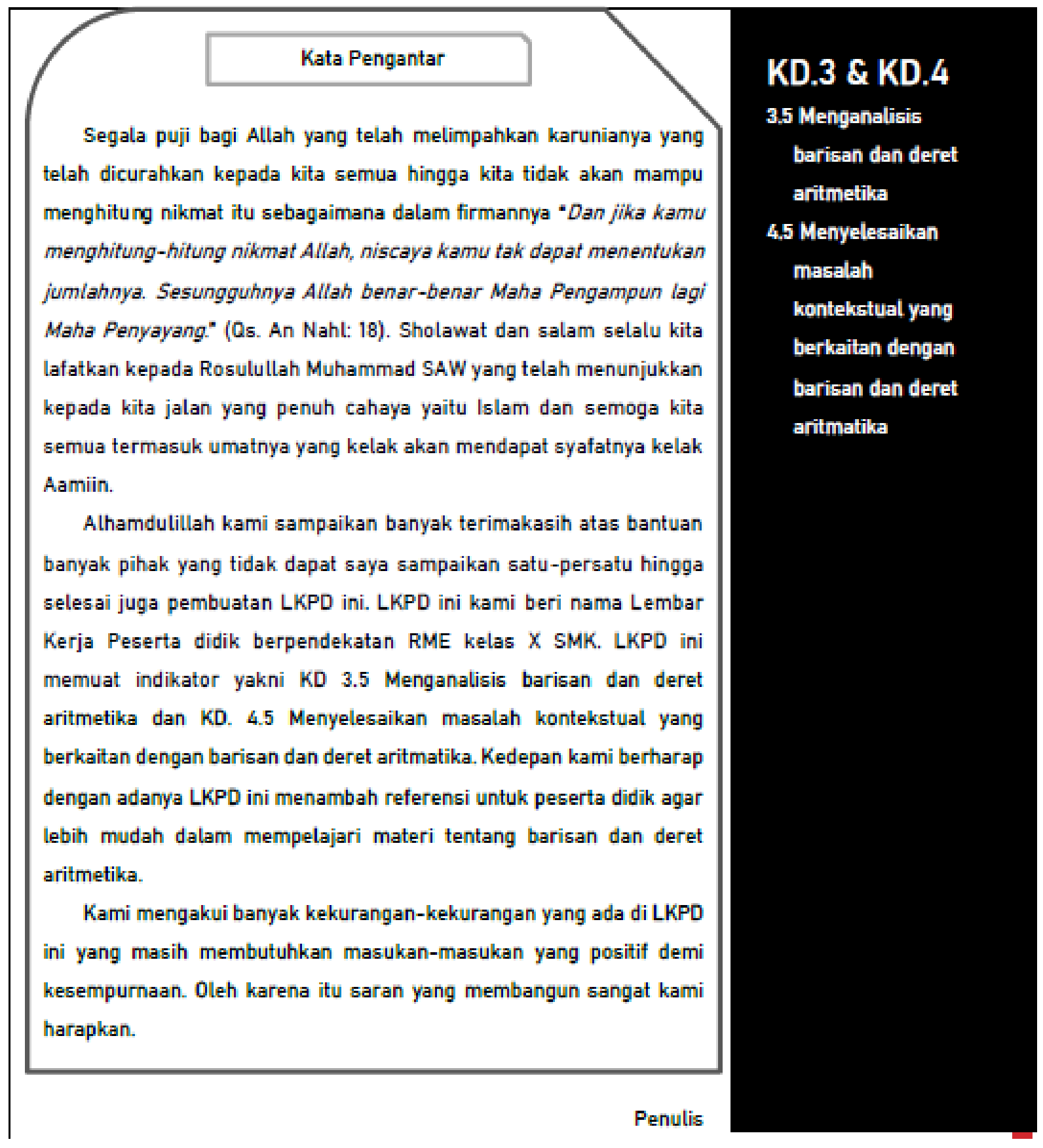

Figure 3. Preface Design

The next sheet is a table of contents, containing the page number of each material. The preparation of this table of contents is intended so that users can easily find out the position of the material or part that will be known quickly, so there is no need to linger open one by one sheet when wanting to understand the contents of all these worksheets. The table of contents design plan can be found in figure 4 below: 


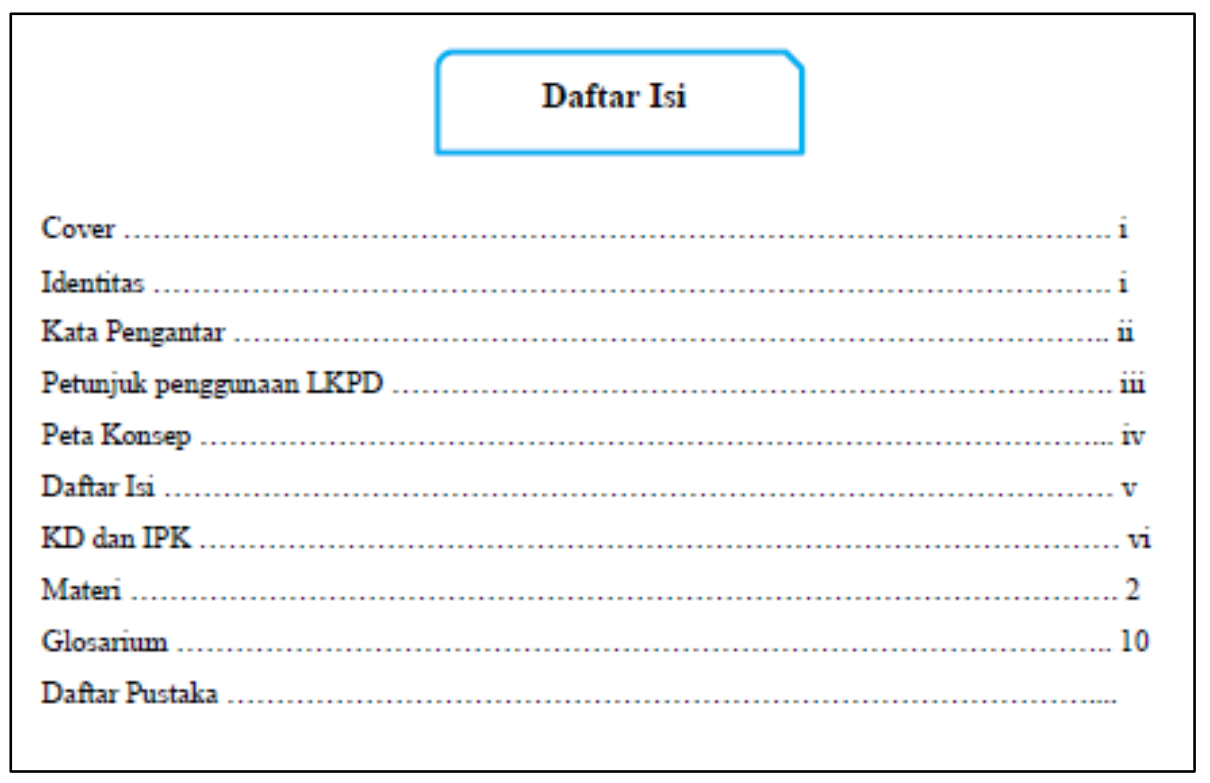

Figure 4. Table of Contents for Student Worksheets

The next sheet, namely the fifth sheet, contains core competencies or basic competencies, and learning objectives. Core competencies or basic competencies are abilities that must be achieved or mastered by students during their learning. Therefore, the contents of the student activity sheet that are made do not come out of the objectives to be achieved. Also it is included later when making evaluation questions in order to measure competencies to be achieved. While the learning objectives are plans for the results to be obtained after studying the material. The design plan for this sheet can be seen in Figure 5 as follows:

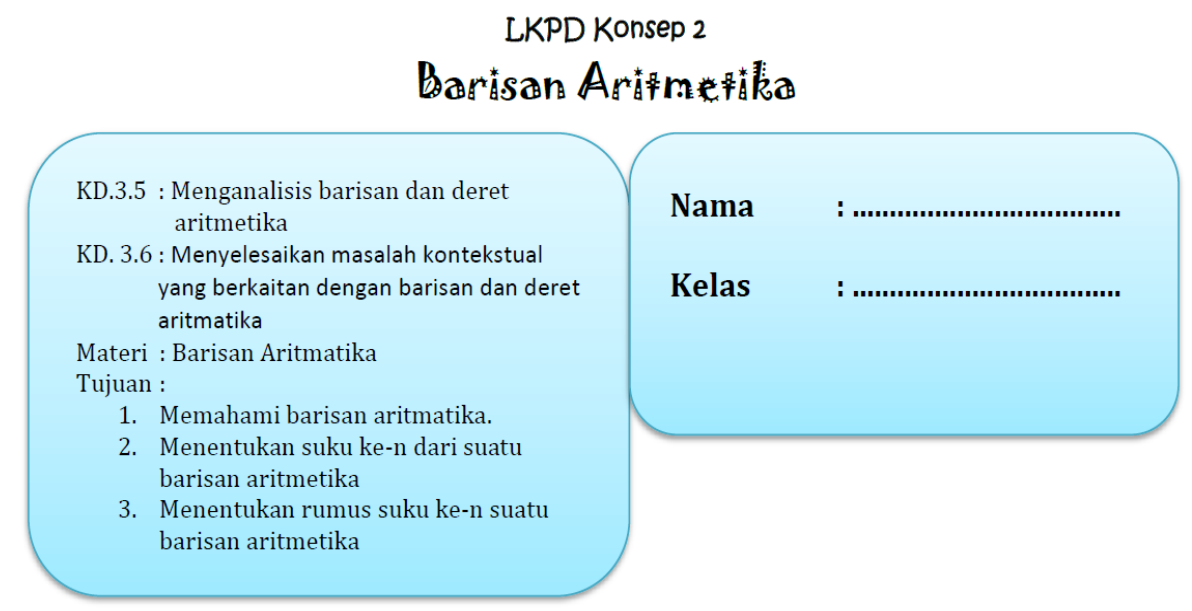

Figure 5. Learning Objective Sheet

Next, the sixth sheet contains contextual problems or the use of real contexts that students must try to solve. The use of contextual problems is made so that students can provide solutions related to these problems. The problem is that students can solve it based on the chosen model, namely RME, because RME is a learning model whose learning character is based on human activities so mathematics must be linked to the daily context of students. This design plan, as shown in Figure 6 , is as follows: 


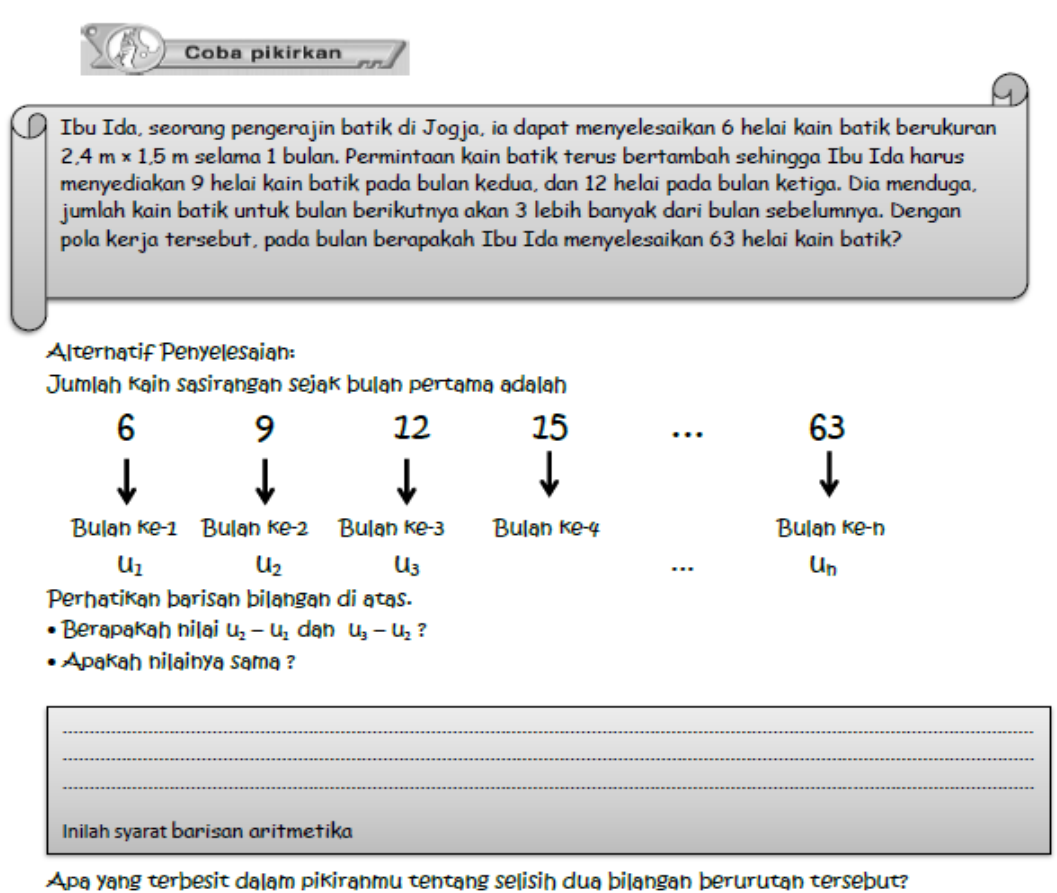

Apa yang terbesit dalam pikiranmu tentang selisih dua bilangan berurutan tersebut?

- Selisih antara dua suku berurutan dinamakan beda, biasanya dilambangkan dengan b.

Figure 6. Design Sheets Using Real Context

From the existing contextual problems students then try to solve them. Students are asked to provide alternative answers in accordance with their subsequent understanding, and students construct problems that have been investigated to form mathematical models. The form of the activity sheet referred to is in accordance with Figure 7 below:
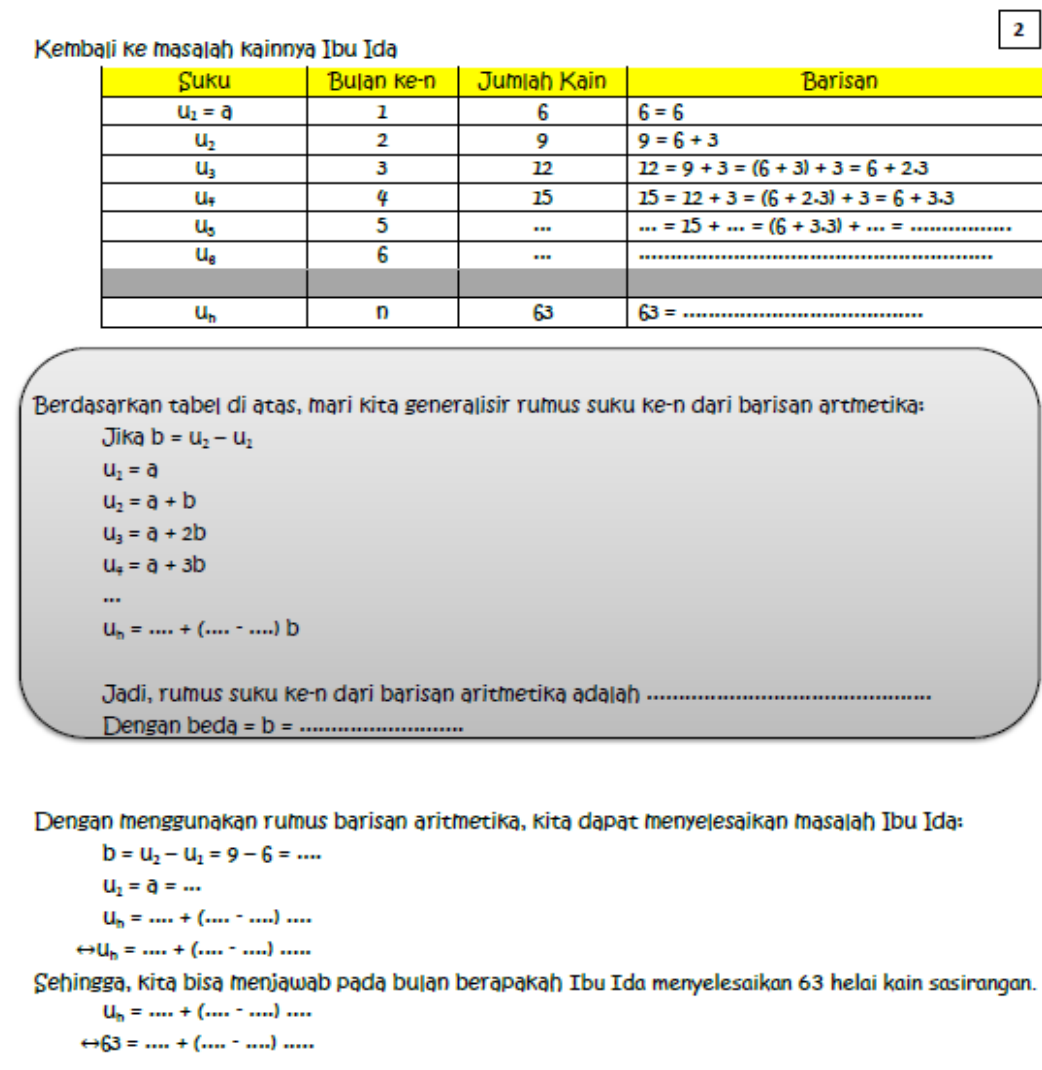

Jadi, Ibu Ida menyelesaikan 63 helai kain pada bulan ke- .....

Figure 7. Construction Sheet 


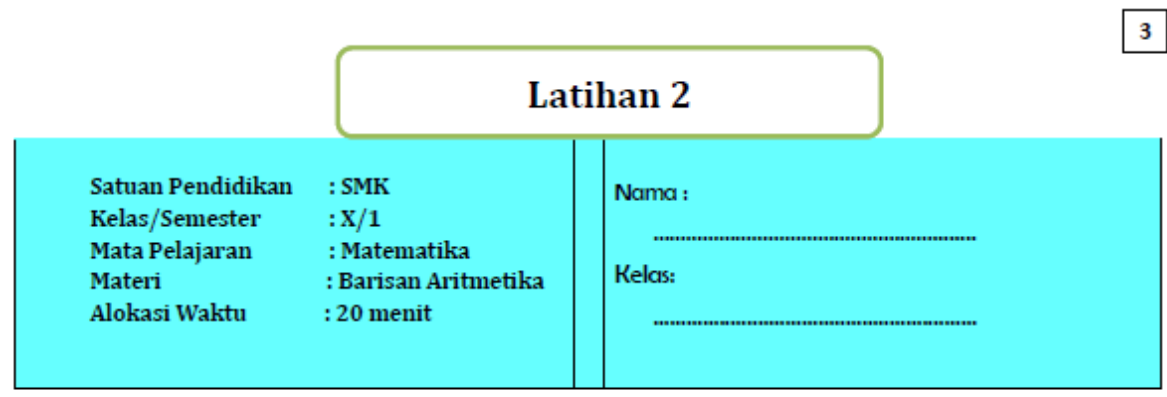

Mari kita aplikasikan rumus barisan aritmetika yang telah kita temukan.

Kerjakanlah soal-soal di bawah ini.

1. Carilah suku yang diminta pada setiap barisan aritmetika berikut.

a. $8,11,14, \ldots$ (Suku ke-27)

b. $49,42,35, \ldots$ (Suku ke-19)

2. Suku keempat suatu barisan aritmetika sama dengan 22, sedangkan suku kesembilannya sama dengan 64.

a. Carilah suku pertama dan beda barisan itu.

b. Carilah rumus suku ke-n.

3. Dalam suatu permainan, setiap kenaikan satu tingkat mendapat bonus nilai 1.000 poin. Jika seorang bermain dengan nilai awal 245 poin, pada tingkat berapakah dia mendapat nilai 15.245 poin?

4. Panjang sisi-sisi sebuah segitiga membentuk barisan aritmetika. Keliling segitiga itu $252 \mathrm{~cm}$ dan sisi terpendeknya $72 \mathrm{~cm}$. Tentukan panjang kedua sisi lainnya.

Figure 8. An Activity Sheet

This sheet contains the findings of various ways to solve different problems, which were found independently or with the help of friends and teachers to summarize the activities carried out. Next, train students in understanding the material prepared activity sheets, as shown in Figure 8.

The questions on this activity sheet are used to measure students' understanding the lessons they have learned.

The design of the student worksheets was then validated by two media experts, Bibi Imna Zanu, S.Pd.Si. who was a mathematics teacher from Muhammadiyah 1 Yogyakarta Vocational School and a member of the Yogyakarta Vocational Mathematics teacher discussion and second by Ika A mirin, S.Pd.Si. who is a teacher of the Muhammadiyah 3 Wates Vocational School and a member of the
Mathematical teacher discussion of the Vocational School of Kulonprogo Regency. This selection is because they have long been a mathematics teacher at the Vocational School, so they have the ability to become validators of this student worksheet.

The validation results show that the design of the student worksheets from four indicators of design validation, product indicators of more than $80 \%$ are appropriate, mathematical communication indicators of more than $80 \%$ are appropriate, student worksheet indicators of more than $60 \%$ are appropriate and standard process indicators RME of more than $60 \%$ are appropriate. The results of design validation are clearer according to table 2 : 
Table 2. Results of Design Validation

\begin{tabular}{|c|c|c|}
\hline The indicator of Validation Design & The results & Suggestion \\
\hline Product Indicator & $\begin{array}{c}\text { Design of more than } 80 \% \text { according to Core } \\
\text { Competencies and Basic Competencies }\end{array}$ & there is no \\
\hline $\begin{array}{c}\text { Mathematical Communication } \\
\text { Indicators }\end{array}$ & $\begin{array}{c}\text { More than } 80 \% \text { design includes indicators of } \\
\text { mathematical communication }\end{array}$ & $\begin{array}{c}\text { In connecting the model, it needs to start } \\
\text { from the easy one to the more difficult }\end{array}$ \\
\hline Student Worksheet Indicator & $\begin{array}{c}\text { The design of more than 60\% includes indicators } \\
\text { for preparing student worksheets }\end{array}$ & Evaluation practice questions added \\
\hline $\begin{array}{c}\text { An indicator of Realistic Mathematics } \\
\text { Education Process Standards }\end{array}$ & $\begin{array}{c}\text { Design of more than } 60 \% \text { includes a standard } \\
\text { mathematical education process standard }\end{array}$ & $\begin{array}{c}\text { The use of the RME model in the student } \\
\text { worksheet is added }\end{array}$ \\
\hline
\end{tabular}

As for the calculation of the learning media feasibility criteria, there is a table of ideal assessment criteria that is used as a reference for evaluating the student worksheet, which is in accordance with the following table 3 :

Table 3. Results of Design Validation

\begin{tabular}{|c|c|c|}
\hline Validator & Score & Criteria \\
\hline Validator 1 & 3,9 & good \\
\hline Validator 2 & 3,7 & good \\
\hline
\end{tabular}

From the table above it can be concluded that the worksheets of students which are made to have criteria at a good level can be continued at the next stage, namely the development stage.

\section{Conclusions}

This study produces worksheets of students which are close to Realistic Mathematics Education with the aim of improving students' mathematical communication skills. The design of the student worksheet consists of cover design, introductory design, table of contents design, design of learning goal sheets, design of real context usage sheets, design of the contour sheet, and design of the training sheet. The results of media expert validation concluded that this student's worksheet had a good score so that it was worth using with revisions according to the validator's suggestions. This research is limited only to the design stage. Furthermore, it will be carried out in the development stage and testing the effectiveness of the student worksheets that have been made.

\section{Acknowledgements}

We express our gratitude to the head of the Yogyakarta 1 Muhammadiyah Vocational School who gave the permission from the beginning of the study to complete this research.

\section{REFERENCES}

[1] T. Laurens, F. A. Batlolona, J. R. Batlolona, \& M. Leasa. How
Does Realistic Mathematics Education (RME) Improve Students' Mathematics Cognitive Achievement? Eurasia Journal of Mathematics, Science and Technology Education, 14(2), 569-578, 2018.

[2] E. F. Yang, B. Chang, H. N. Cheng, \& T. W. Chan. Improving pupils' mathematical communication abilities through computer-supported reciprocal peer tutoring. Journal of Educational Technology \& Society, 19(3), 157, 2016.

[3] D. Kaya, \& H. Aydin. Elementary mathematics teachers' perceptions and lived experiences in mathematical communication. Eurasia Journal of Mathematics, Science \& Technology Education, 12(6), 1619-1629, 2016.

[4] E. De Freitas. What were you thinking? A Deleuzian/Guattarian analysis of communication in the mathematics classroom. In Contesting Governing Ideologies (pp.96-111). Routledge, 2017.

[5] F. Viseu, \& I. B. Oliveira. Open-ended tasks in the promotion of classroom communication in mathematics. International Electronic Journal of Elementary Education, 4(2), 287-300, 2017.

[6] R. Sunday ana, T. Herman, J. A. Dahlan, \& R. C. Prahmana. Using ASSURE learning design to develop students' mathematical communication ability. World Transactions on Engineering and Technology Education, 15, 245, 2017.

[7] S. Rahmi, R. Nadia, B. Hasibah, \& W. Hiday at. The Relation between Self-Efficacy toward Math with the Math Communication Competence. Infinity Journal, 6(2), 177-182, 2017.

[8] E. R. Ottmar, S. E. Rimm-Kaufman, R. A. Larsen, \& R. Q. Berry. Mathematical knowledge for teaching, standards-based mathematics teaching practices, and student achievement in the context of the responsive classroom approach. American Educational Research Journal, 52(4), 787-821, 2015.

[9] A. Bicer, R. M. Capraro, \& M.M. Capraro. Integrating writing into mathematics classroom as one communication factor. The Online Journal of New Horizon in Education, 4(2), 58-67, 2014.

[10] M. Aufa, S. Saragih, \& A. Minarni. Development of Learning Devices through Problem Based Learning Model Based on the Context of Aceh Cultural to Improve Mathematical Communication Skills and Social Skills of SMPN 1 Muara Batu Students. Journal of Education and Practice, 7(24), 232-248, 2016

[11] M. Maulana, Suparman. Development of Students Worksheet based on Realistic Mathematics Education in Indonesia. International Journal of Engineering \& Technology, 7(4.30), 
45-49, 2018.

[12] S. R. Harahap. Development of Learning Device Based on a Realistic Approach to Improve Problem Solving Ability Mathematics of Student at Junior High School, 333-338, 2017.

[13] M. K. Kim, \& M. K. Cho. Design and Implementation of Integrated Instruction of Mathematics and Science in Korea. Eurasia Journal of Mathematics, Science \& Technology Education, 11(1), 3-15, 2015.

[14] W. A. Basuki, \& A. Wijaya. The Development of Student Worksheet Based on Realistic Mathematics Education. In Journal of Physics: Conference Series (Vol. 1097, No. 1, p. 012112). IOP Publishing, 2018.

[15] N. R. 'Afifah, Suparman. Design of Student Worksheets based on Learning Cycle 5E Learning Model for VIII Junior High School Students in Indonesia. International Journal of Engineering \& Technology, 7(4.30), 16-20, 2018.

[16] R. Handayani, Suparman. Design of Mathematics Student Worksheet based on Realistic Mathematics Approach to Improving the Mathematical Communication Ability Student of Class VII Junior High School in Indonesia. International Journal of Engineering \& Technology, 7(4.30), 31-35, 2018.

[17] T. Akma, Suparman. The Design of Student Worksheet Problem based Learning to Improve Problem Solving Ability of the Eighth-Grade Students Junior High School in Indonesia. International Journal of Engineering \& Technology, 7(4.30), 11-15, 2018.

[18] F. H. Amran, Suparman. Design of Student Worksheets based on Learning Cycle to Improve Ability of Mathematics Representation Students of Class XIII Junior High School in Indonesia. International Journal of Engineering \& Technology, 7(4.30), 21-25, 2018.

[19] L. E. Lathifah, Suparman. Design of Mathematics Students Worksheet based on Discovery Learning Approach to Improving Mathematical Representation Ability Students of Grade VII Junior High School in Indonesia. International Journal of Engineering \& Technology, 7(4.30), 26-30, 2018.

[20] F. Isdiarti, Suparman. Design Development Learning Media Based PMRI Oriented Capabilities Study Creative Students Grade VII of Junior High School in Indonesia. International Journal of Engineering \& Technology, 7(4.30), 50-52, 2018.

[21] Zulfaneti, S. Rismen, \& M. Suryani. Validity analysis of development lesson plan and student worksheet based realistic mathematics education. In AIP Conference Proceedings (Vol. 1707, No. 1, p. 070001). AIP Publishing, 2016.

[22] R. M. Branch. Instructional design: The ADDIE approach (Vol. 722), Springer Science \& Business Media, New York, 2009.

[23] G. M. Piskurich. (2015). Rapid instructional design, Wiley, 2015. 